\title{
Local Perceptions on the Impact of Drought on Wetland Ecosystem Services and Associated Household Livelihood Benefits: The Case of the Driefontein Ramsar Site in Zimbabwe
}

\author{
Thomas Marambanyika *D, Upenyu Naume Mupfiga (D), Tatenda Musasa and Keto Ngwenya \\ Department of Geography and Environmental Studies, Midlands State University, Gweru P Bag 9055, Zimbabwe; \\ mupfigau@staff.msu.ac.zw (U.N.M.); r134325y@students.msu.ac.zw (T.M.); r141231e@students.msu.ac.zw (K.N.) \\ * Correspondence: marambanyikat@staff.msu.ac.zw
}

check for updates

Citation: Marambanyika, T.; Mupfiga, U.N.; Musasa, T.; Ngwenya, K. Local Perceptions on the Impact of Drought on Wetland Ecosystem Services and Associated Household Livelihood Benefits: The Case of the Driefontein Ramsar Site in Zimbabwe. Land 2021, 10, 587. https://doi.org/ 10.3390/land10060587

Academic Editors: David J. Abson, Gladman Thondhlana,

Sheunesu Ruwanza,

Elandrie Davoren, Staffan Rosell, Andrea Belgrano, Regina Lindborg, Charlie Shackleton, Ken Findlay and James Gambiza

Received: 26 January 2021

Accepted: 13 April 2021

Published: 2 June 2021

Publisher's Note: MDPI stays neutral with regard to jurisdictional claims in published maps and institutional affiliations.

Copyright: (c) 2021 by the authors. Licensee MDPI, Basel, Switzerland. This article is an open access article distributed under the terms and conditions of the Creative Commons Attribution (CC BY) license (https:// creativecommons.org/licenses/by/ $4.0 /)$.
Abstract: The paper assesses local people's perceptions on the impact of drought on wetland ecosystem services and the associated household livelihood benefits, focusing on the Driefontein Ramsar site in Chirumanzu district, Zimbabwe. Field data were obtained using a questionnaire from 159 randomly selected households, key informant interviews and transect walks. The study findings show that provisioning, regulating and supporting services are severely affected by a high frequency of drought, occurring at least once every two years, compared to cultural services. There is a reduction in water for domestic use and crop farming, pasture for livestock, fish, thatch grass and ground water recharge. Although cultural services such as traditional rain-making ceremonies and spiritual enhancement are largely unaffected by drought, the wetland's aesthetic value was reported to be diminishing. The habitat and breeding areas of endangered crane bird species were perceived to be dwindling, affecting their reproduction. All the household heads are not formally employed and largely depend on the wetland resources for food and income. However, drought is adversely affecting wetland-based agricultural activities that are key pillars of the households' economy. Therefore, there is a need for alternative livelihood strategies that enable local communities to adapt to drought impacts without exerting more pressure on the declining wetland resources.

Keywords: drought; ecosystem services; household economy; rural livelihoods; wetland

\section{Introduction}

Wetlands, generally defined as areas that are temporarily or permanently inundated with water [1-3], are one of the most productive natural ecosystems in the world. They provide many ecosystem services that benefit humans in their social and economic activities as well the maintenance of the physical environment $[2,4]$. Ecosystem services are the benefits derived by humans from healthy, productive ecosystems and the natural environment [2,5]. According to the Millennium Ecosystem Assessment [6], wetland ecosystem services can be classified as provisioning (e.g., fish, clean water and food), regulating (e.g., flood and erosion control, climate regulation and water purification), supporting (e.g., habitat, soil formation and photosynthesis) and cultural (e.g., education, spiritual enhancement and aesthetic).

Wetland ecosystem services [5,7] have an economic and biodiversity value that far outweighs many terrestrial ecosystems [2]. The estimated global economic value of wetland goods is US\$70 billion a year [8]. Globally, the services delivered by wetlands are approximately US\$14 trillion annually [2]. Therefore, wetlands provide ecosystem goods and services that are vital for people's livelihoods and survival, especially in developing countries such as Zimbabwe, where crop cultivation, livestock grazing, fruits, firewood extraction and medicine are extracted directly from this ecosystem [9-12]. Water availability is the key driver of the aforementioned wetland use and benefits [2-4]. The continued provision of ecosystem services depends on the wetland's ecological health [13,14]. Despite 
their contribution to human livelihoods, the provision of wetland ecosystem services is threatened by natural and human factors [15]. Inadvertently, wetland degradation and loss are being experienced at unprecedented rates at various scales, from global to local levels [16-18]. In Zimbabwe, more than 50\% of the wetlands were lost between 1980 and 2020 [4].

Whilst the human causes of wetland loss such as land reclamation and draining for agriculture, pollution, invasive species, sand and gravel harvesting, urban development and mining $[2,5]$ can be managed, natural factors such as climate change and drought are projected to have devastating effects on wetland ecosystems [16,19]. Globally, the frequency of drought has been increasing in light of climate change [20,21], affecting the wetlands' ecological conditions to different extents [7,22]. Zimbabwe has not been spared, as evidenced by multi-decadal rainfall variability associated with drought conditions [20,23]. Drought, generally defined as a period of abnormally dry weather long enough to cause a serious hydrological imbalance [20], is ranked as the most frequent natural disaster in Zimbabwe between 1980 and 2011 [24]. The highest frequency of drought in Zimbabwe was recorded between 2000 and 2010, where $70 \%$ of the years in that decade experienced droughts [24]. This shows that the frequency of droughts is increasing in the country.

Furthermore, all districts in Zimbabwe have been affected by drought during the past thirty years, with varying levels of severity and frequency; hence, there are variations in drought vulnerability and exposure in the country's communities [25]. To date, the impact of drought in Zimbabwe has been assessed mainly on agriculture [25,26]. However, there are inconclusive findings on the specific impacts of climate change and drought on freshwater resources, including wetlands [27]. Given the fact that water is the primary defining factor of a wetland as a resource, a high frequency of droughts has the potential to erode many wetland ecosystem services. Therefore, there is a need to assess the local people's perceptions on how drought has been affecting wetland ecosystem services and put the livelihoods of dependent rural communities at risk. Generally, drought is a major risk facing rural households in Zimbabwe [28] and is further projected to increase in frequency in light of climate change [27].

Meanwhile, the majority of households in Zimbabwe's rural areas (where 60.7\% of the total number of national households are located) are living under poverty, with $76.9 \%$ deemed as poor [29]. This situation is likely to be worsened by the degradation and loss of natural resources such as wetlands, where households are obtaining direct and indirect benefits for daily livelihood sustenance. For example, Mahlatini et al. [12] and Marambanyika et al. [30] revealed that wetlands are key pillars of rural households' food security and income. Therefore, understanding the impact of drought on wetland ecosystem services and the associated livelihood benefits provides essential information on how drought possibly increases the vulnerability of different communities. These findings will assist in the identification of suitable intervention strategies to mitigate the perceived socio-economic impact of drought, information necessary to ensure the achievement of the United Nations Sustainable Development Goals (2015 to 2030) such as no poverty, zero hunger and cleaner water and sanitation.

Wetlands have been used for cultivation and livestock grazing since time immemorial [31-33]. However, due to the threats of crop cultivation and livestock overgrazing to the wetland ecosystem, the colonial governments, for example in Zimbabwe, banned wetland agriculture in order to abate wetland drying and erosion [32,34]. This was met with resistance in communal areas since wetland agriculture had been the backbone of the rural economies, even before the colonization of Africa [35]. In the post-independence era in Zimbabwe, the enforcement of wetland regulation laws was relaxed and the law was later changed to promote sustainable wetland utilisation as the government noticed that wetland farming continued to be a vital pillar of the rural economy [32,35] and the exclusion of local people was contributing to unstainable practices [35]. Meanwhile, drought and increasing human population numbers have been forcing people to migrate into or extend farming in the wetland areas where they grow high-value vegetables and green 
maize for food and income [30,31]. As a result, wetlands continue to form an integral part of the rural agricultural system throughout the year and offer an insurance against rain-fed crop failure [32]. Due to climate change, the occurrence of drought is likely to increase, meaning the importance of wetlands to rural agriculture and economies will continue as they provide the necessary household nutritional and income support $[30,36]$. Therefore, drought will continue to exert pressure on wetland ecosystem services due to declining production in dryland farming.

Although empirical evidence has proven that droughts have become a frequent phenomenon in Southern Africa [37], locals have their own perceptions of drought occurrence. Perceptions are described as a range of beliefs, judgements and attitudes [38]. Human perceptions vary as they depend on one's physical environment and its characteristics, social organization and norms and the characteristics of the people [39-41]. Therefore, previous drought experiences can shape an individual's memory and influences how they define drought and the ability of locals to make informed decisions on local adaptation strategies [38,42]. While studies have shown that, based on views of the people, human activities such as agriculture, tourism and urban development have significant negative impacts on wetland ecosystems [40-44], there is dearth of information on local people's perceptions on the impact of a natural phenomenon such as drought on ecosystem services. This is despite the observation that local people's perceptions on ecosystems goods and services are important variables that affect implemented conservation initiatives [45]. As a result, the ability of ecosystems to continuously provide these services depends on understanding local people's perceptions [46].

The specific objectives of this study are to examine: (1) households' perceptions on drought frequency and severity; (2) the perceived impact of drought on ecosystem services; and (3) the impact of drought on the livelihoods of households that depend on the wetland ecosystems.

\section{Materials and Methods}

\subsection{Description of the Study Area}

The study was carried out at Driefontein wetland in Ward 20 of Chirumanzu district of Zimbabwe (Figure 1). The wetland (623 ha), which is located on Zimbabwe's central plateau (190 23' S; $30047^{\prime}$ E), is one of the seven Ramsar sites in the country. It is a floodplain, submerged by water throughout the year. The wetland recharges nearby Shashe and Nyororo streams as well as the Sebakwe River located in the Sanyati catchment area, that eventually drains into the Zambezi River. Driefontein wetland has wet grasslands and patches of Miombo woodlands (dominated by Brachystegia spiciformis), conditions that provide a home to three globally threatened bird species- the wattled crane, grey crowned crane and the secretary bird [47-49]. The wetland is home to about half of the crane bird species in the country [47] and is found in Zimbabwe's natural region III that receives an annual rainfall total between 600 and $800 \mathrm{~mm}$. The mean annual temperatures range from $12{ }^{\circ} \mathrm{C}$ during winter to $32{ }^{\circ} \mathrm{C}$ in summer, with frost common in winter [50].

Ward 20, where the wetland under study is located, has a total of 8037 people and an average household size of 4.3 persons, with food poverty prevalence at $18.9 \%$ [44]. The average general poverty prevalence level is between 60 and 76\% [51], a situation that makes poor households rely more on wetland resources. The Driefontein community largely depends on agriculture to improve their livelihoods. This has necessitated an increase in wetland encroachment by cultivation [52]. Several types of vegetables are grown in individual gardens. These include beans and tomatoes that fetch high market prices in the nearby towns and cities, for example, Beitbridge, Gweru and Masvingo. Therefore, there is a need to understand how the livelihoods of the local people are being affected by the impact of drought on the wetland ecosystem. 


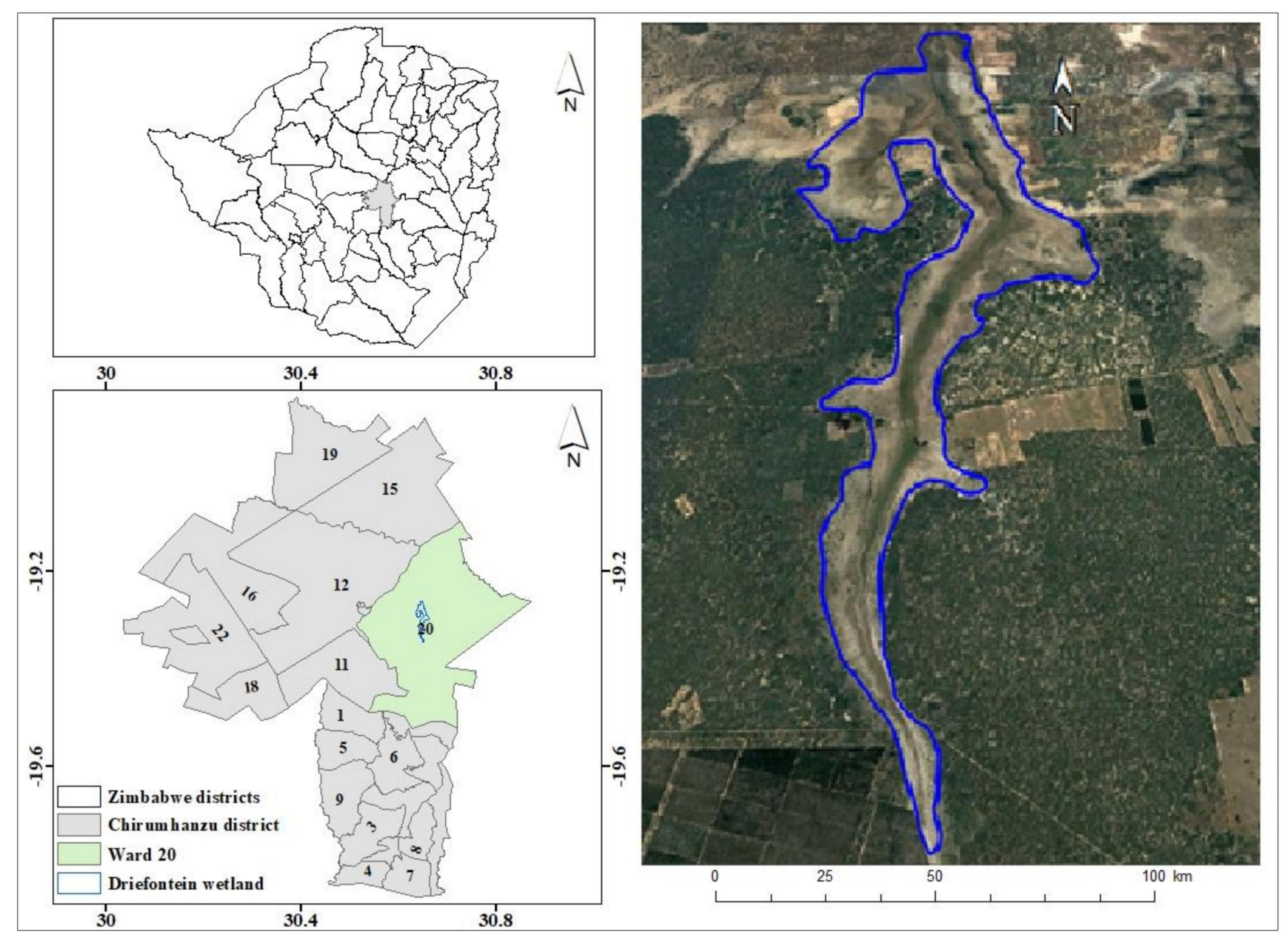

Figure 1. Driefontein wetland, Zimbabwe.

\subsection{Data Collection and Analysis}

Field data were obtained during the dry winter month of June 2020, when the households were engaging in wetland land use activities such as farming, due to the presence of water. A questionnaire, key informant interviews and direct observations checklist were used as research instruments to obtain information from the local people and the wetland environment. The household sample size was determined using the Raosoft sample size calculator with a confidence level of $95 \%$ and a margin of error of $5 \%$. The total number of households surrounding the wetland was 270 . Therefore, using the Raosoft software, the recommended sample size for the survey was 159 households. The selection of households from villages representing the sampling frame was carried out using random number tables and the community register. In this case, households were assigned numbers on the register and were picked following the rules of random number tables. In the absence of the household head, the eldest and most knowledgeable person present participated.

The questionnaire obtained information on the households' perceptions on drought frequency and severity in the area, the observed impact of drought on the wetland ecosystem services and how drought has been affecting livelihoods dependent on the wetland resources. To obtain information on people's perceptions, several questions were asked. Based on a list of known wetland ecosystem services (from literature) presented in a table, as option responses, for each category of ecosystem services (provisioning, cultural, regulating and supporting), the household respondents were asked to first indicate (by ticking) the wetland services affected by drought and, second, to determine the perceived degree of impact of drought on each of the selected wetland services. A five-point rating scale (1 (not sure), 2 (not severe), 3 (moderate), 4 (severe) and 5 (very severe)) was used to indicate 
each respondent's perceived degree of impact of drought on each of the selected wetland ecosystem service. For example, a question was asked: Using information in Table 1, indicate/tick the regulating services affected by drought and rate the impact of drought on each. Room was given for the respondents to add ecosystem services known in their area that could have been omitted on the predetermined option responses. Other questions asked were: What are the livelihood options based on wetland ecosystem services? Is there any change in household livelihood options as a result of the impact of drought on wetlands? Information on the socio-economic attributes of household heads (gender, age, education level, marital status, duration of stay) and family structure (size and dependency ratio) was also gathered. The questionnaire was designed in English and translated into the local language, Shona, to ensure easy interpretation by the households.

Semi-structured interviews, guided by a template with pre-set questions on the impact of drought on wetland ecosystem services, were carried out with three purposively selected traditional leaders and the Wetland Committee chairperson. The three traditional leaders were asked questions such as: What are the ecosystem services derived from the wetland? What is the impact of drought on the wetland's provisioning, cultural, regulating and supporting services? How has drought affected each of the mentioned ecosystem service? What are the household livelihood options based on wetland ecosystem services and how were these affected by drought? The Wetland Committee chairperson provided responses to questions such as: What is the impact of drought on wetland ecosystem services? What are the household livelihood options based on wetland ecosystem services? Is there any change in household livelihood options as a result of the impact of drought on the wetland? Direct observations, guided by a checklist and two senior villagers who were engaged as field assistants, were carried out through transect walks, to assess the status of the wetland, the types of land use and nature of ecosystem services provided by the wetland as well as the perceived changes noted. Ethical clearance was obtained from the Midlands State University, Zimbabwe. Informed consent forms were completed by the participants prior to their participation in the study.

Qualitative data from the questionnaire, key informant interviews and direct observations were analysed using the thematic analysis method [53]. Guided by the study objectives, the emerging themes were noted and reported as the study results. Quantitative data were coded and analysed at a 95\% confidence interval in the SPSS version 27. Descriptive statistics were generated to show the frequency of households' responses on various questions, for example, frequency and severity of drought, the impact of drought on provisioning, regulating, supporting and cultural as well as the livelihood options affected by changes in the wetland conditions. The quality of household livelihood was measured using the estimated income as a proxy indicator. A dependent $t$-test was used to establish the difference between the total annual household income obtained from the wetland and the total annual household income.

\section{Results and Discussion}

\subsection{Socio Demographic Information of Household Respondents}

Questionnaire survey results revealed that $65 \%$ of the household respondents were males and 35\% females. Ninety-five percent of the household respondents were married and the remaining $5 \%$ were single. The mean age group of household respondents was 46 to 55 years. Although $60 \%$ of household heads were at least 46 years old, there were wide variations in the respondents' age ( $\mathrm{SD} \pm 1.35)$. All the surveyed household heads were not formally employed and were highly depend on the wetland's resources. This was confirmed by the Wetland Committee chairperson, who revealed that without the wetland's all-year-round benefits, poverty levels could have been very high in the area. Therefore, the wetland is a key pillar of the local community's livelihood. About 55\% of the questionnaire respondents attained primary education whilst the remaining $45 \%$ had secondary level education qualifications. This shows that the community was literate considering that primary education is the minimum benchmark of literacy in Zimbabwe. 
This may imply that the local people had better comprehension of how ecosystem services were affected by droughts.

Ninety-five percent of the households had a population size of between 5 and 10 persons. The remaining five percent had less than five persons. This shows that the families were large and needed more resources to survive, a situation that puts pressure on the wetland under drought conditions. Traditional leaders revealed that all the people around the wetland were resettled starting from the year 2000. Eighty-five percent of the households had stayed in the area for at least 10 years whilst the remaining $15 \%$ had stayed for less than a decade. All the households had been using the wetland from the time they were resettled, a sign that the wetland is a key pillar of the community's livelihoods and the local people had knowledge of changes in wetland ecosystem services. Ninetyfive percent of the households are located within a $1 \mathrm{~km}$ radius of the wetland, with the remaining $5 \%$ within $2 \mathrm{~km}$. There was no major difference in the distances travelled by households to the wetland, as shown by a standard deviation of $1 \pm 0.22 \mathrm{~km}$. The abovementioned households' characteristics and organization could have influenced the local people's perceptions on the impact of drought on the wetland ecosystem services, as will be discussed in the subsequent sections.

\subsection{Drought Prevalence, Frequency and Severity}

All the household respondents indicated that drought was experienced in the area. However, their perceptions on the frequency of drought vary (Figure 2). The majority of the households, constituting $80 \%$ of the total number of surveyed households, indicated that drought occurs at least once every two years $(40 \%)$ or once every five years $(40 \%)$ (Figure 2). About $15 \%$ of the households revealed that drought was experienced every year. Only $5 \%$ of the respondents indicated that drought occurs once in more than 10 years. The households' perceptions on drought prevalence in the area clearly showed that the frequency was high, making drought a common natural phenomenon in the area. These findings tally with those of Nangombe [24] and Frischen et al. [25] who noted that drought was occurring on an almost annual basis in Zimbabwe since the year 2000. This period coincides with the time the surveyed households started settling in the study area, that is, from 2000; hence, the local people's perceptions on drought prevalence seem to conform to the findings of the previous studies undertaken in Zimbabwe. Therefore, as highlighted by Frischen et al. [25], there is a need to think about appropriate interventions that can be put in place to mitigate the impacts of drought in rural communities whose livelihood options are directly linked to natural resources.

The majority of the households $(60 \%)$ revealed that drought was associated with a significant reduction in the amount of rain normally received for effective dry land farming and had a very severe impact on the wetland's health condition, especially its hydrology and vegetation. For instance, the water quantity and quality were reported to have been declining, whereas the vegetation structure and composition was perceived as being altered due to the periodic low rainfalls experienced during drought years. However, $15 \%$ and $25 \%$ of the households rated the impact of drought on the wetland ecosystem as moderate and severe, respectively. These households noted that although the amount of water in the wetland was low during drought periods, at least they were able to abstract some water to irrigate small portions in their gardens. Therefore, the impact of drought on the wetland and other natural resources was visible to all the people living in the Driefontein area, although its perceived magnitude varied according to individuals. The variations in the negative impact of drought on wetland ecosystems has also been noted globally by previous studies $[19,54]$, meaning that more location-specific studies on the impact of drought on natural resources and the dependent communities need to be undertaken [55]. Therefore, the findings of this study show that the local communities in the Driefontein area need to plan for drought mitigation and/or adaptation strategies in order to improve their quality of life as wetland resources have not been spared by the recurring drought. 


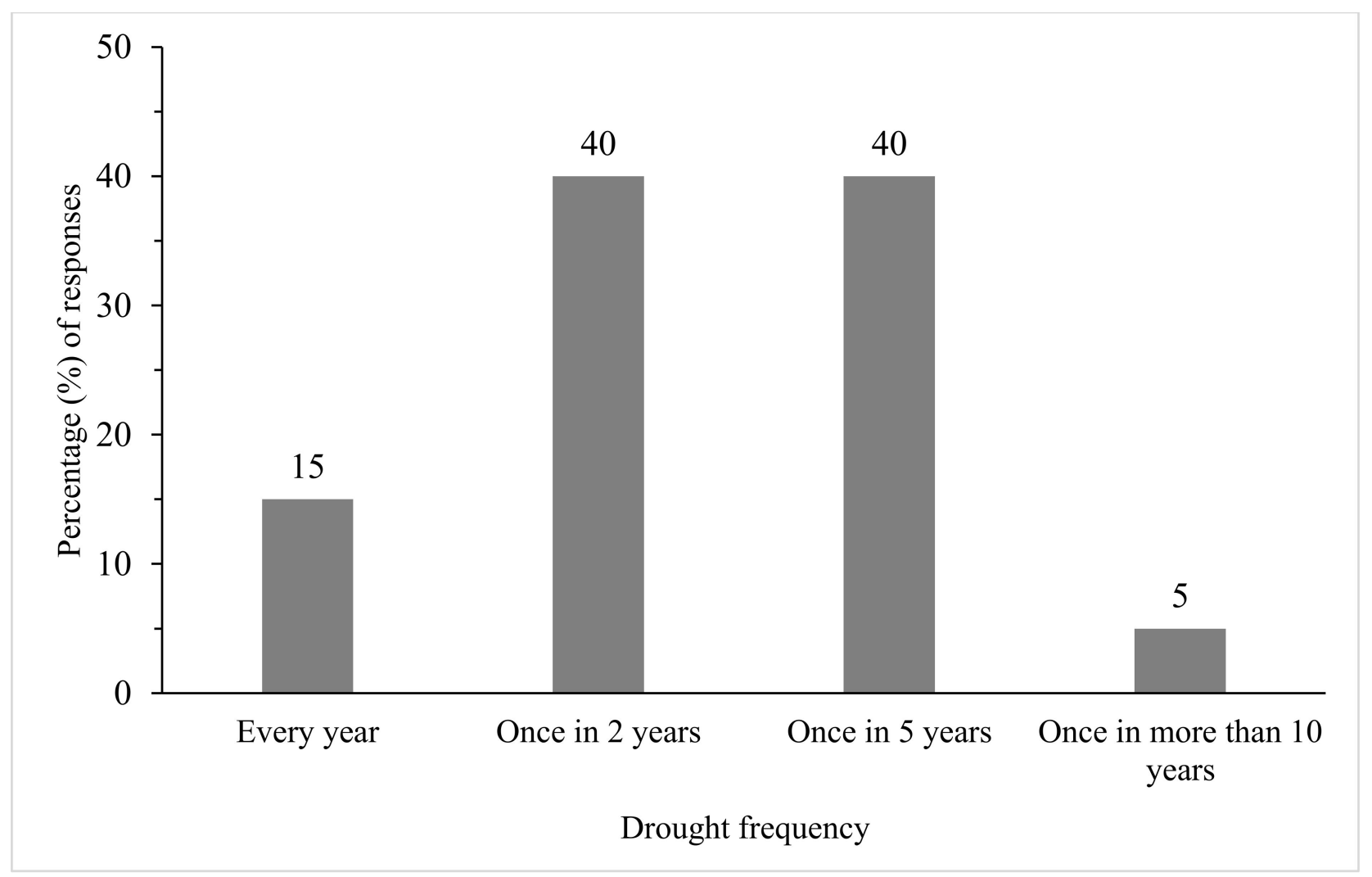

Figure 2. Household perceptions on perceived frequency of drought occurrence.

\subsection{Impact of Drought on Wetland Provisioning Services}

The households demonstrated that they understood the provisioning services provided by the Driefontein wetland. These are clean water, food, pasture for livestock, thatch grass, herbs and fish (Figure 3). Eighty percent of the questionnaire respondents indicated that drought had a very severe impact on the water quantity available for crop cultivation as the amount of available water in the wetland has been declining. Similar results by previous studies have also attributed a reduction in water levels to changing climatic conditions characterised by extreme weather events such as drought $[25,48,55]$. In the Driefontein area, households were irrigating their horticultural and cereal crops using water obtained from the wetland since cultivation in the wetland was legally prohibited (Figure 4a). Thus, the frequent occurrence of droughts had resulted in all-year-round crop cultivation in and around the wetland, thereby putting more pressure on the declining water resources. Frischen et al. [25] indicated that a high dependence on rain-fed agriculture by rural communities as the primary economic sector had made them more susceptible to drought, and this may explain the observed extension of cultivation into the wetland area where moist conditions exist. Therefore, a lack of information about resilience and adaptive capacity to droughts results in communities resorting to any available means of survival including over-utilising the fragile wetland ecosystems [56].

About $65 \%$ of the questionnaire respondents revealed that the effect of drought on livestock grazing is very severe (Figure $4 \mathrm{~b}$ ), severe (20\%), moderate $(5 \%)$ and not severe $(10 \%)$. These perceptions were based on a reduction of the wetland grasses largely attributed to cattle overgrazing due to the decline in forage in the surrounding dryland. The Wetland Committee chairperson estimated that more than 100 cattle rely on the wetland for grazing and water. This was observed as further straining the already dwindling water in the wetland due to successive low amounts of rainfall received in the area over the past two decades. Therefore, wetland-based agricultural activities supported by water presence and healthy vegetation were adversely affected by reduced rainfall amounts [57] and high 
temperatures, conditions associated with drought, a situation that was likely to negatively affect the households' livelihood.

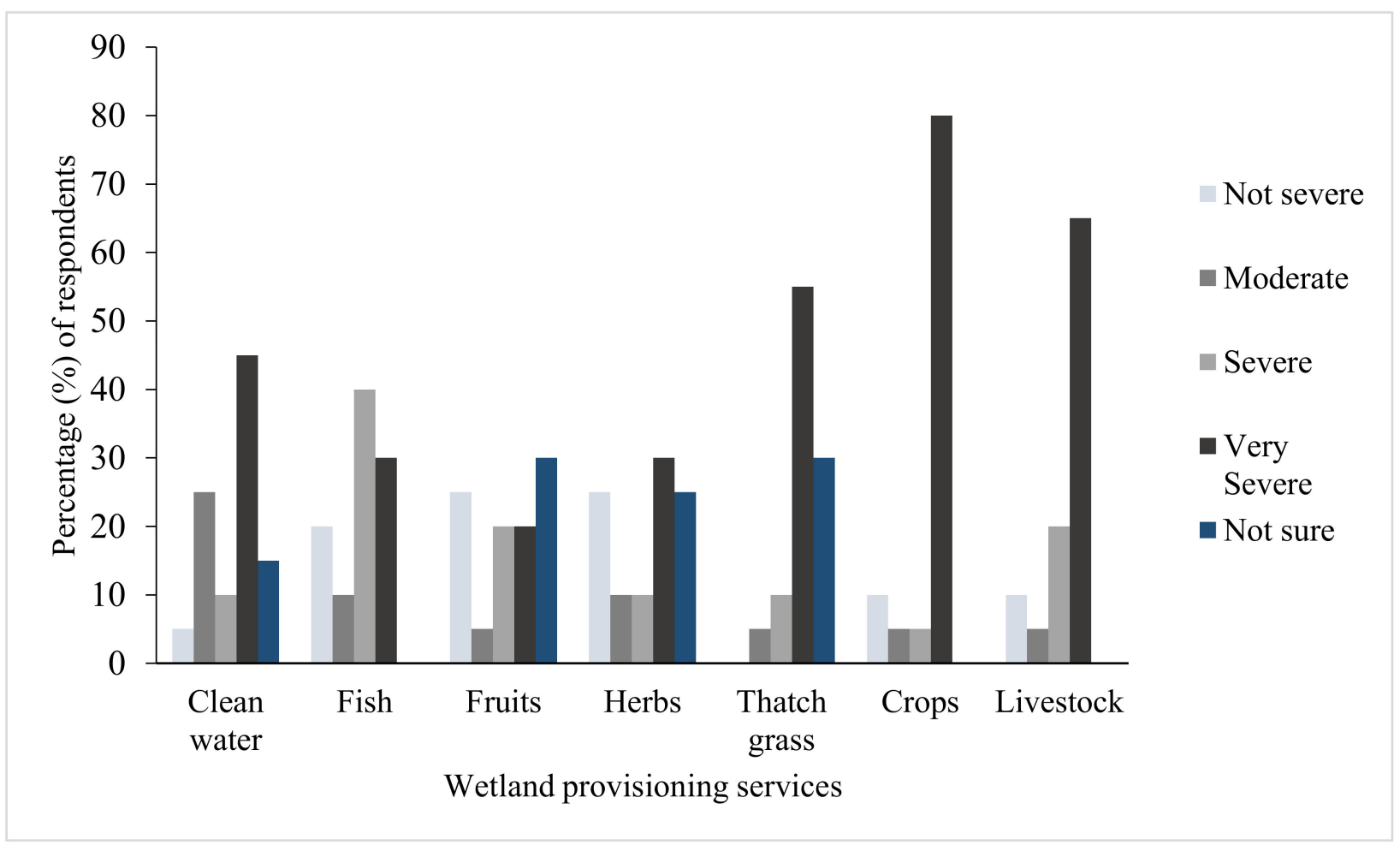

Figure 3. Perceived impact of drought on wetland provisioning services.

(a)

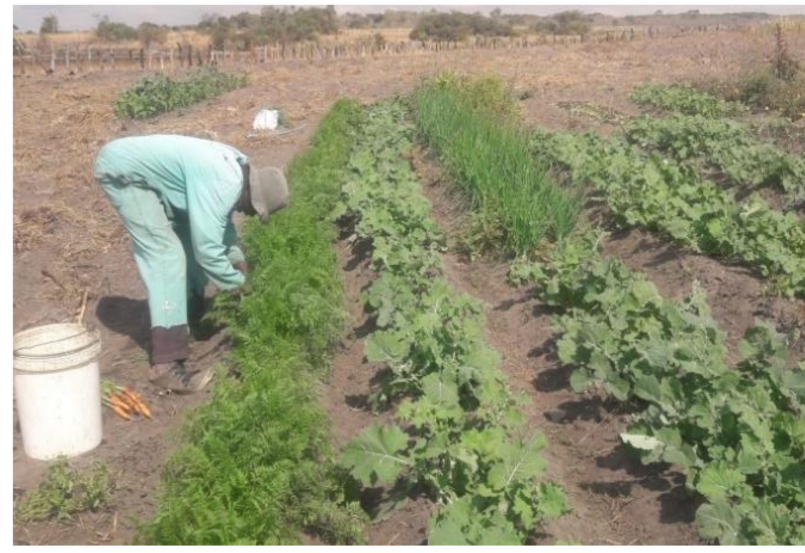

(b)

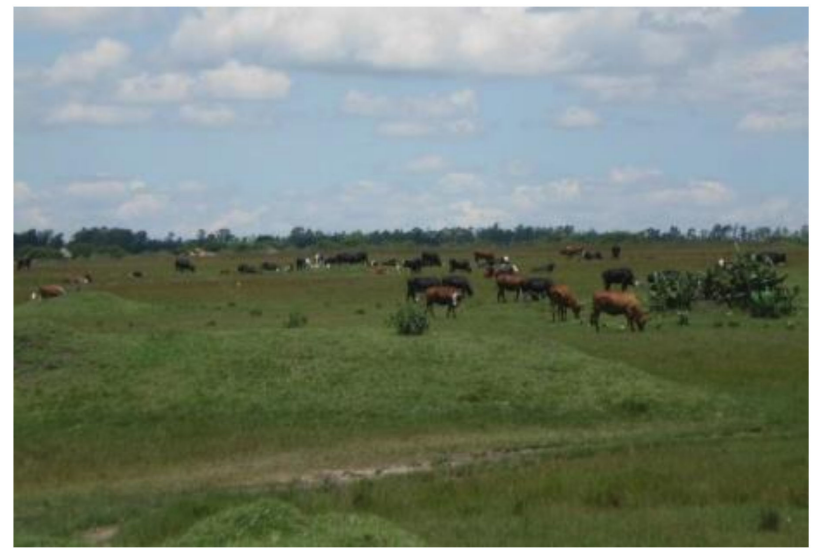

Figure 4. (a) Horticultural activities; (b) Livestock grazing within the wetland.

Forty-five percent of the households indicated that the drought's impact on clean water obtained from the wetland for domestic use was very severe as the amount of water accessed was insufficient for daily households needs. This was attributed to the declining wetland water table and inadequate ground water recharge of deep wells (used as sources of domestic water) perceived to be linked to the wetland. Therefore, during drought years, the water security of the community was adversely compromised [58]. The effects of drought on water levels were observed to be clear and pronounced, a situation that was also reported in similar studies conducted elsewhere [59]. This may suggest that proactive measures need to be implemented to mitigate the effect of drought on water sources recharged by the wetlands. Moreover, the provision of clean water by the wetland [6] improves the sanitation of rural resource-constrained communities as they were reported 
by the Wetland Committee chairperson not to have the capacity to buy water disinfectants. Therefore, drought was reported to be depriving the local people safe sources of water. For instance, households downstream of the wetland indicated that they experienced serious clean water shortage after the two successive droughts in seasons 2018/2019 and 2019/2020. The remaining $30 \%$ of households who rated the impact of drought on clean water as not severe to moderate were either living in areas located far away from the wetland or they did not understand the connection between the wetland and their sources of water.

Fishing in the wetland was now limited because fishponds were drying up due to the frequent occurrence of droughts. This was confirmed by the household respondents that rated the impact of drought on fish as severe $(40 \%)$ and very severe (30\%). These findings may explain why the traditional leaders and the Wetland Committee chairperson were appealing for assistance to construct ponds using sandbags in order to impound more water that escaped from the wetland during the years when good rainfall was experienced. The drying of water ponds had resulted in a reduction in fish production. The disappearance of pools of water during drought periods had also been observed to be a common natural phenomenon in the wetlands [60], meaning droughts have been largely affecting water resources in wetlands at various scales, although the impact tends to vary $[55,58]$. Moreover, $85 \%$ of the household respondents revealed that drought had a severe to very severe impact on the amount of thatch grass harvested from the wetland area (Figure 3). The households end up incurring additional costs to buy thatch grass for periodic renewal of roofing of their huts. Therefore, the reduction in thatch grass adds a cost to the household economy. The remaining $5 \%$ of households who rated the impact of droughts on thatch grass as not severe revealed that their houses were either roofed by metal sheets or asbestos.

Twenty-five percent of the households were not sure about the impact of drought on herbs and fruits. The traditional leaders revealed that many households did not want to show knowledge of herbs since it may be associated with witchcraft. This had been attributed to the adoption of western cultural practices that have adulterated the local tradition. The three traditional leaders indicated that most of the households relied on clinics and hospitals for medical assistance. Few Syzygium cordatum species were observed as the remaining fruit trees. According to $30 \%$ of the households, the fruit trees were becoming extinct due to the changing hydrological condition of the wetland attributed to a high frequency of drought [25]. The study findings generally show that provisioning services in the Driefontein wetland were perceived to be largely negatively affected by frequent droughts.

\subsection{Impact of Drought on Wetland Regulating Services}

The households demonstrated knowledge of regulating services offered by wetlands, such as ground water recharge, water purification and flood control. Most household respondents $(60 \%)$ indicated that drought had a very severe impact on ground water recharge (Figure 5). These households attributed the reduction in water levels in wells located in their gardens and deep wells at homesteads to the changing hydrological condition of the wetland. These sources of water were reported to take a long time to recharge, and in the worst cases, they dried completely during prolonged drought periods. The decline in water levels in the wells was perceived to be an indicator of declining water presence in the wetland, a situation also noted in the previous studies [2,4]. Therefore, the effect of drought on the wetland was also affecting the water sources that were linked to the wetland ecosystem. Households confirmed that although cultivation was prohibited within the wetland core area as part of conservation efforts, the amount of water in this area was declining during droughts, a sign according to them that this natural phenomenon was responsible, a situation also noted in other parts of the world [54,59]. 


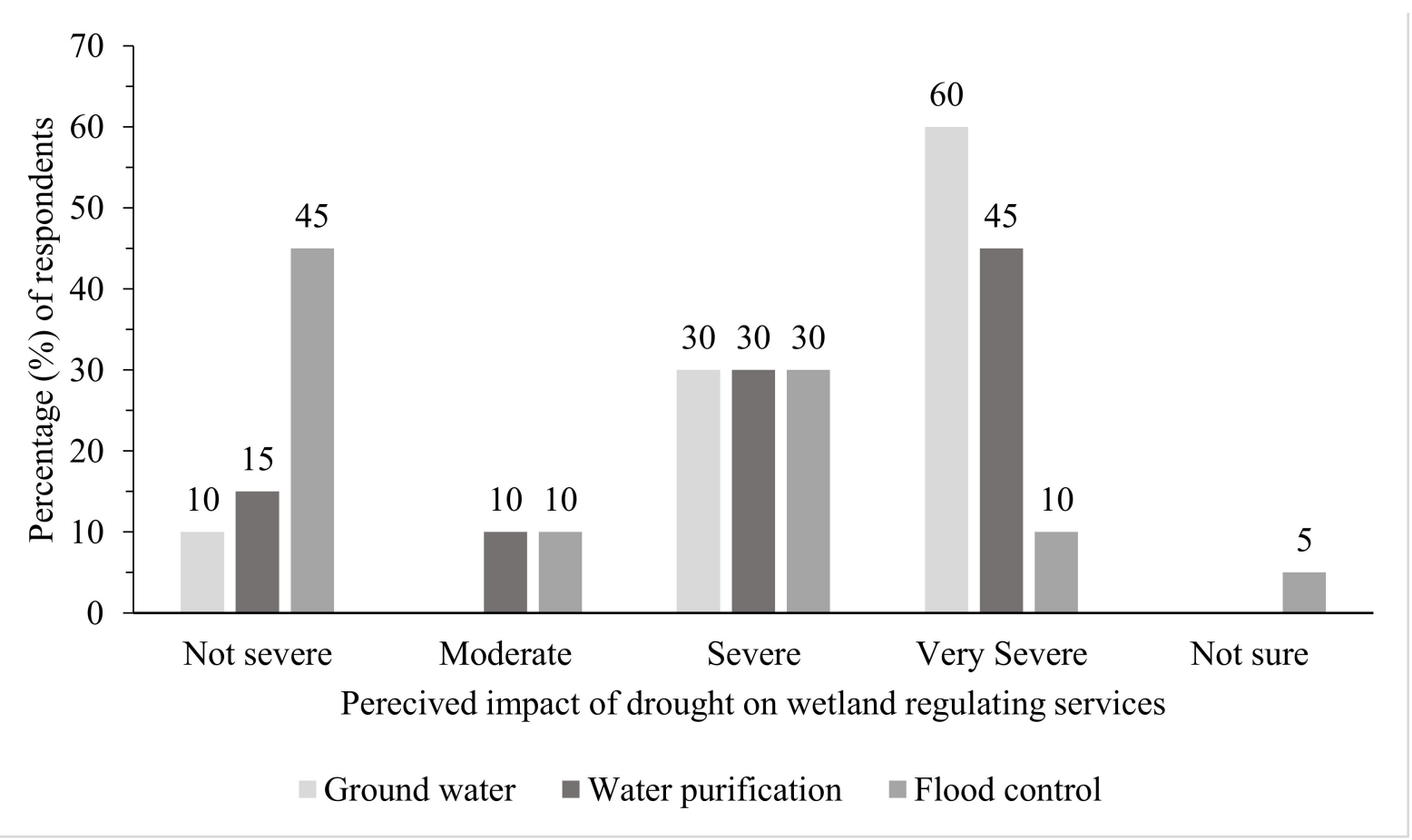

Figure 5. Perceived impact of drought on wetland regulating services.

Moreover, $85 \%$ of the household respondents revealed that drought had a moderate to very severe impact on the wetland's water purification function (Figure 5). This was confirmed by the three traditional leaders and the Wetland Committee chairperson who revealed that wetland water normally turns reddish in colour during the drought years, making it unsuitable for humans and livestock to drink. The observed changes in water condition can be attributed to a decrease in available water as a result of drought that normally led to a change in the water quality parameters [54], due to altered flows which compromise purification processes [61]. Therefore, drought was compromising water security of the households since they largely depended on clean water fetched from the wetland. Although $45 \%$ of the households thought that drought had no effect on wetland flood control, $40 \%$ pointed out that drought affected the wetland's ability to control floods as they rated the impact of drought on flood control as severe or very severe. This was attributed to a decline in wetland vegetation that normally enhances water retention during the rainy season [21]. The bare surface areas observed in the wetland were likely to increase surface run-off, as observed by Marambanyika et al. [57] in their assessment of wetland health in communal areas of Zimbabwe.

\subsection{Impact of Drought on Wetland Supporting Services}

The majority of the household respondents $(60 \%)$ indicated that drought has a very severe impact on animal habitats (Figure 6). The breeding areas of the globally threatened bird species, such as the grey crowned crane (Balearica regulorum), secretary bird (Sagittarius serpentarius) and wattled crane (Bugeranus carunculatus), were reported to be disappearing. This was confirmed by the three traditional leaders, who further indicated that uncontrolled veld fires due to drought induced the drying of wetland vegetation, destroying cranes' nesting sites, eggs and chicks. The high frequency of drought over the past two decades had been observed as gradually decreasing the number of endangered crane bird species. Therefore, instead of the wetland controlling veld fires as one of its ecosystem functions, the wetland is now prone to frequent burning due to the high fuel load of dry grass. According to Fakarayi et al. [47] four local conservation groups (LCGs) were established by BirdLife Zimbabwe to conserve cranes from the increasing frequency of veld fires induced by the recurring drought conditions. 


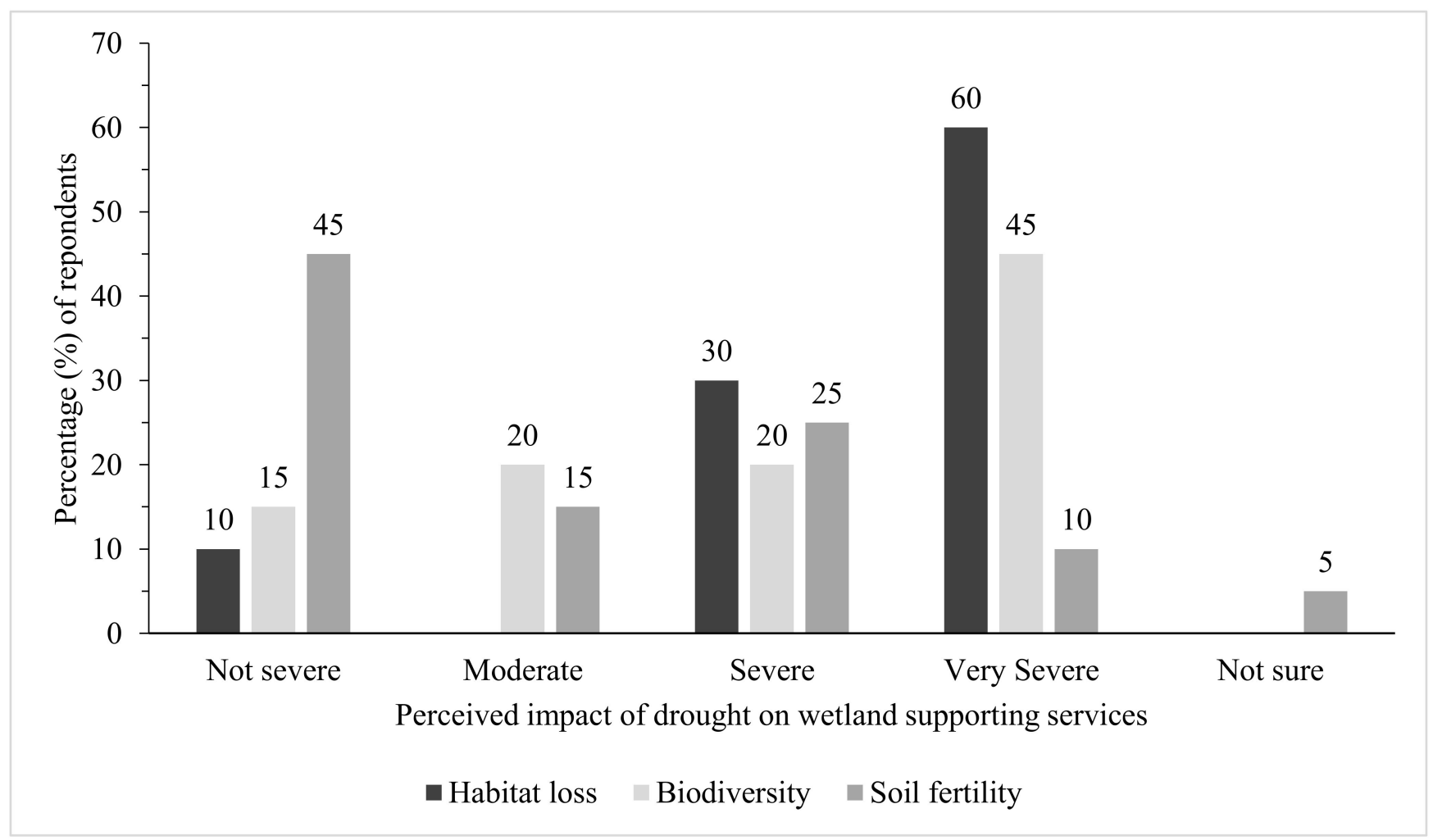

Figure 6. Perceived impact of drought on wetland supporting services.

Moreover, $45 \%$ of the households revealed that biodiversity had been declining. There was an observed increasing infestation of the wetland by invasive species such as Terminalia sericea, Hibiscus henriquesii and Eragrostis dolichostachya. These ruderal species were common in the wetland fringes and bare dry areas in some parts of the wetland. Therefore, drought was observed to have been altering the wetland's vegetation community structure and composition, as the wetland invaders form monotypes, which were altering the habitat structure and lower biodiversity [62,63]. Most households (45\%) were not sure if drought was affecting soil fertility. This was attributed to the fact that crop cultivation is not taking place within the wetland but on the fringes where the community was applying both organic and inorganic fertilisers in their gardens to improve crop yields. However, droughts in some areas were observed to be increasingly impacting on wet soils and leading to their degradation [58], and this may explain why $10 \%$ of the households rated the impact of drought on soil fertility as very severe.

\subsection{Impact of Drought on Wetland Cultural Services}

About $65 \%$ of the household respondents highlighted that drought had no severe to moderate impact on the aesthetic value of the Driefontein wetland (Figure 7). However, the remaining 35\% rated the impact of drought on the aesthetic value of the wetland as severe to very severe, as evidenced by the reduction in water-loving plant and animal diversity. This was attributed to many burnt areas as a result of fire occurrences that were more frequent due to the presence of dry vegetation. A similar situation of fire outbreaks was observed in the wetlands of the Matobo district [44], meaning that effective fire management strategies need to be adopted to minimise threats posed by drought-induced fire outbreaks in the wetlands. Furthermore, 25\% of the household respondents highlighted that the impact of drought on spiritual enhancement activities such as worshipping is not severe, whilst $30 \%$ were not sure. These respondents were either not using the wetland as a meeting place for churches or did not believe in traditional spiritual activities undertaken at wetlands, such as appeasing the ancestors. It was observed that some people continued to worship in the serene parts of the wetland area, where water was available for baptism. Hence, the 
remaining $45 \%$ rated the impact of drought on spiritual enhancement as moderate to very severe (Figure 7). They revealed that a reduction in rains had been causing the drying of the water ponds used for baptism purposes.

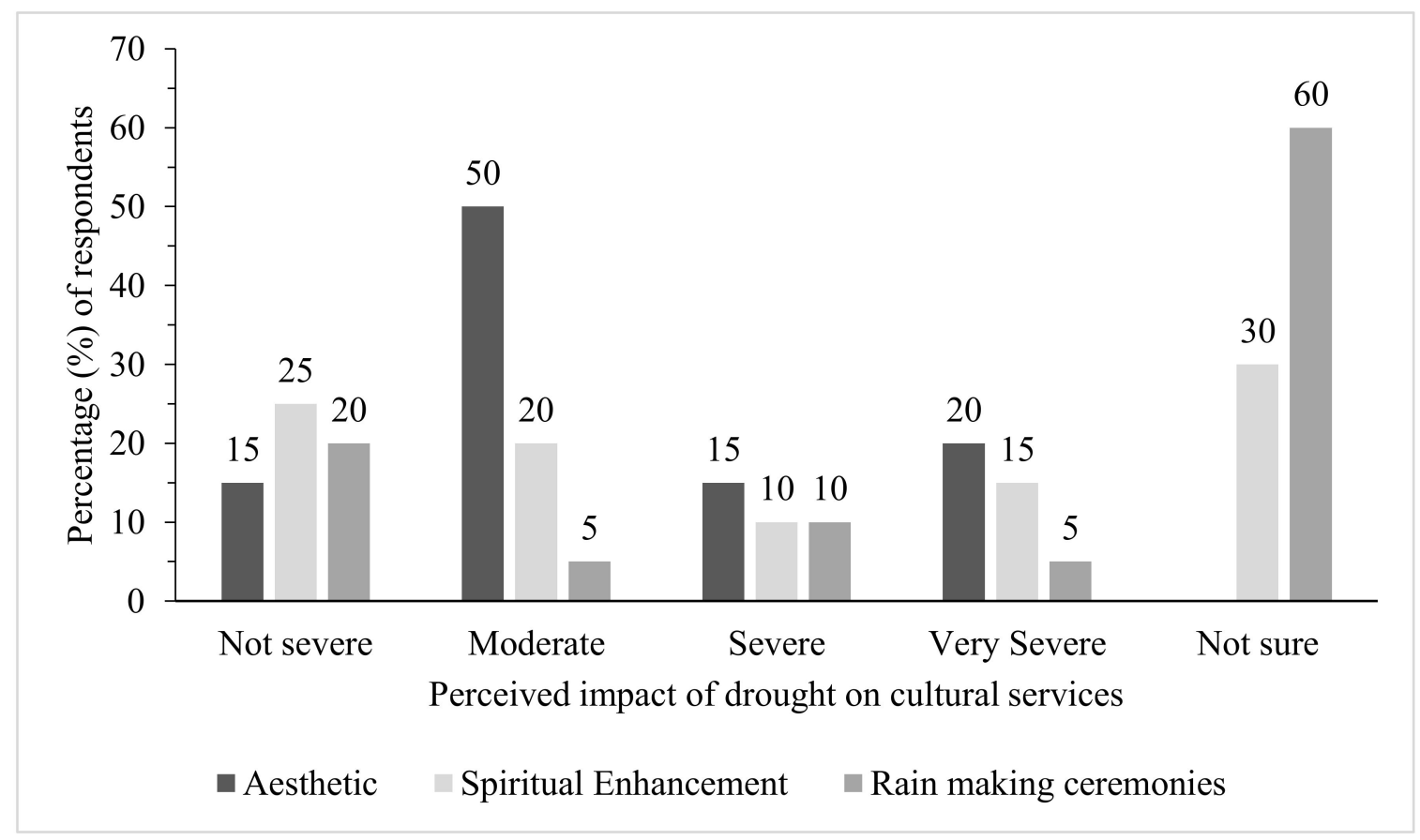

Figure 7. Perceived impact of drought on wetland cultural services.

The majority of the household respondents $(60 \%)$ were not sure about the impact of drought on rain-making ceremonies since the practice was abandoned due to changes in culture and technology. The community now relied on weather information from the Meteorological Services Department of Zimbabwe and cloud seeding carried out by the government. The traditional leaders revealed that these modern initiatives diminished the importance of traditional rain-making ceremonies, although the practice was still performed by a few elderly people. The remaining households indicated the impact of drought on rain-making activities at the wetland as not severe $(20 \%)$, moderate $(5 \%)$, severe $(10 \%)$, and very severe (5\%) (Figure 7). Those who rated the impact as moderate to very severe reported that the drying of water was chasing away the rain interceding spirits normally resident in water.

The traditional leaders also revealed that the drying of the wetland ponds was resulting in the death of water weeds, such as Nymphaea caerulea, used in the burial of the dead to suppress their anger. It was believed in the local tradition that when a person dies, the deceased individual had anger about unfinished business, based on their life goals, that may need to be suppressed as it had the potential to destabilise the family harmony. Generally, the findings on the cultural significance of wetlands echo those of Ongoro [64], who argued that since time immemorial, wetlands have been used to perform cultural activities; hence, people were closely linked to these areas. All local leaders also revealed that the wetland was used for education and research purposes by universities and research institutions in the country. These research activities continued in the wetland as efforts were being made to understand the ecological changes in this Ramsar site of international importance. However, the study findings on the perceived impact of drought on cultural services did not reveal the effects of drought on tourism and recreation, an area where research information was reported to be limited, despite these being the most critical economic sectors in many areas [55]. This may suggest that more studies may need to be carried out to strengthen knowledge and policies on the impact of drought on cultural ecosystem services. 


\subsection{Households' Wetland-Based Livelihood Options}

The Driefontein wetland is used for different purposes by people from the surrounding communities (Figure 8). Although households engaged in multiple wetland uses, crop farming was the major land use in the wetland as confirmed by $80 \%$ of the households. Wetland garden produce was sold in the towns and cities of Zimbabwe, especially Beitbridge, Chivhu, Gweru and Masvingo. The questionnaire survey results further showed that the wetland was a major source of water for domestic use $(60 \%)$, livestock (55\%) brickmoulding (55\%) and mushrooms in the surrounding area (Figure 8$)$. The wetland therefore generates most of the food $(77 \%)$ and income $(70 \%)$ for all the surveyed households. This may explain why Ward 20, where the Driefontein wetland is located, had a food poverty prevalence rate of $18.9 \%$, slightly lower than the average $21 \%$ for the whole of the Chirumanzu district [41]. These findings underscore the general notion from other previous studies that wetlands are a critical resource for rural communities' economy [31,41-43,59], and this makes it imperative to devise strategies to mitigate the impact of drought on this natural resource in order to ensure sustainable rural livelihoods [65].

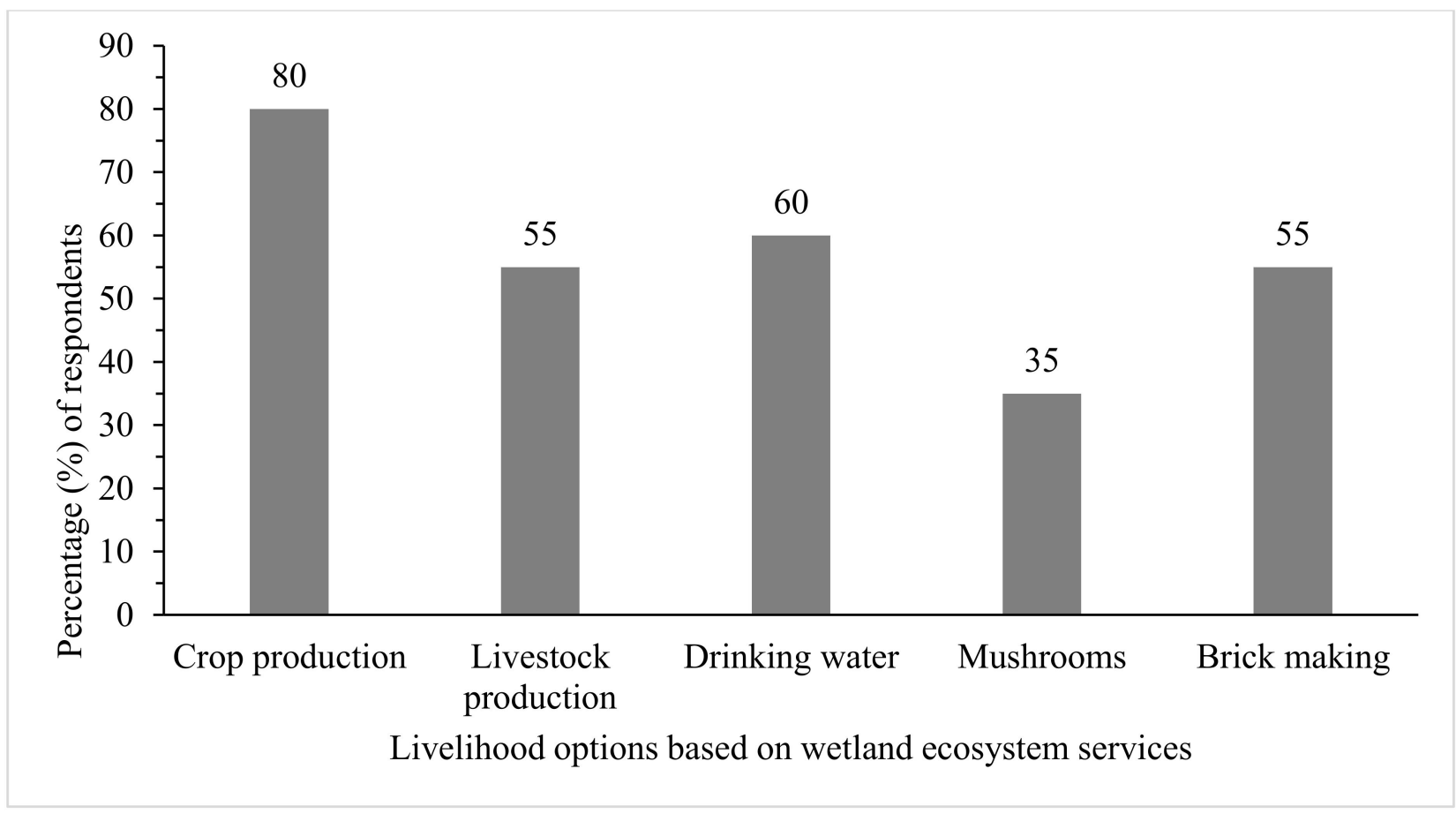

Figure 8. Household livelihood options based on the wetland ecosystem.

The estimated average household annual wetland income was ZWL\$11,750 and the estimated average total household income from different sources, including the wetland was ZWL $\$ 13,105$. It was noted that the majority of the households $(70 \%)$ generated an annual wetland total income above ZWL $\$ 10,000$ whereas about $85 \%$ of the households' total income from different sources, including the wetland was above ZWL $\$ 10,000$. Dependent $t$-test results showed that there was no significant difference between the annual total wetland income and annual household income $(p=0.073)$. This shows that wetland-based land uses provide the bulk of the surveyed households' income, meaning a further decline in the wetland ecosystem health as a result of drought was likely to have negative effects on the household economy. As part of community drought resilience-building initiatives, there is a need to identify alternative livelihood sources for households to minimise their dependency on the threatened wetland ecosystem. 


\subsection{Impact of Drought on Households' Wetland-Based Livelihood Options}

Ninety-five percent of the household heads revealed that the impact of drought on the wetland was negatively affecting their wetland-based livelihood options. Seventy percent indicated that declining water levels resulted in a decrease in crop yield, attributed to reduced farming area or the early cessation of wetland farming activities. Drought, therefore, can lead to reduced yields and income [58,61]. Moreover, the limited livelihood opportunities as a result of drought influence the expansion of cultivation into the wetland, thus increasing its vulnerability to the impact of natural shocks such as drought, as vegetation was cleared for cultivation expansion. Therefore, changes in native wetland vegetation negatively affect the wetland's hydrology [57].

Sixty-five percent of the households reported that cattle pasture was declining due to a reduction in moist conditions. Water for livestock drinking was also reported to be declining over the past two decades due to the increasing frequency of droughts that occurred at least once every two years, as shown by $85 \%$ of the household respondents. The key informants revealed that during drought years, almost all livestock in the area, estimated to exceed 1000 cattle, relied on the wetland for grazing and drinking water. This situation was reported to increase pressure on water and vegetation resulting in wetland conditions degrading as a result of overgrazing and trampling, a position also confirmed by Musasa and Marambanyika [4]. Therefore, livestock health was compromised to an extent that they were of low commercial value when they were sold for food during the drought periods. Therefore, the reduction in the significance of wetland-based agriculture (crop cultivation and livestock pasture) due to drought effects was likely to result in deagrarianisation, and hence, diminished household food security and income. This may ultimately result in increased poverty and dependency on government support by the affected rural community $[66,67]$

About $30 \%$ of the households indicated that wetland fruits such as those from Syzygium cordatum are no longer as abundant as in the past, a position confirmed by traditional leaders as well. This means that the commercialization of the fruits to generate more household income was no longer possible.

\subsection{Wetland Protection in Light of Drought Threats and Human Livelihoods Demand}

Drought has adverse impacts on crop cultivation and livestock production, which were the main pillars of the Driefontein area's livelihoods. However, no measures had been put in place to prepare households for alternative livelihood options in light of the increasing drought frequency. Therefore, using the proposed framework (Figure 9), there is a need to come up with drought adaptation strategies so as to enable rural communities to diversify livelihood options, while at the same time maintaining the ecological integrity of the wetland as set under the Ramsar wise guidelines. Zimbabwe should come up with a drought adaptation framework targeting wetlands since human activities are exacerbating the impact of drought on ecosystems service provision. Initiatives such as water harvesting, effective localised early warning systems, crop produce value addition and conservation farming using drip irrigation have the potential to diversify and stabilise livelihoods under drought conditions. Water harvesting and effective localised early warning systems would assist the local people to effectively plan livelihood options normally undertaken outside wetlands, the failure of which during drought periods meaning that people were bound to be pushed to wetland use. This further dwindled the stressed wetland ecosystem due to arid conditions brought by drought and further reduced the spectrum of wetland ecosystem services, a situation that can work against the protection of this fragile important ecosystem. Therefore, the promotion of non-wetland strategies that address the effects of drought would deflect the drivers of wetland human use, especially for cultivation, since this activity was known to negatively affect a wetland's ecological condition $[4,9,57]$. This resonates with Pandey and Upadhyay [68]'s suggestion that the condition of drought-affected people can be improved by promoting employment-generating activities in non-agricultural sectors. Crop value addition and water use conservation strategies will directly reduce the 
pressure on wetland resources as the amount of water required for agricultural production may be reduced. Moreover, if local communities are well-resourced, they are bound to sustainably use the resources at their disposal, thus ensuring protection, which enables the same wetland ecosystem to continue to provide services in the foreseeable future, even during periods of drought.

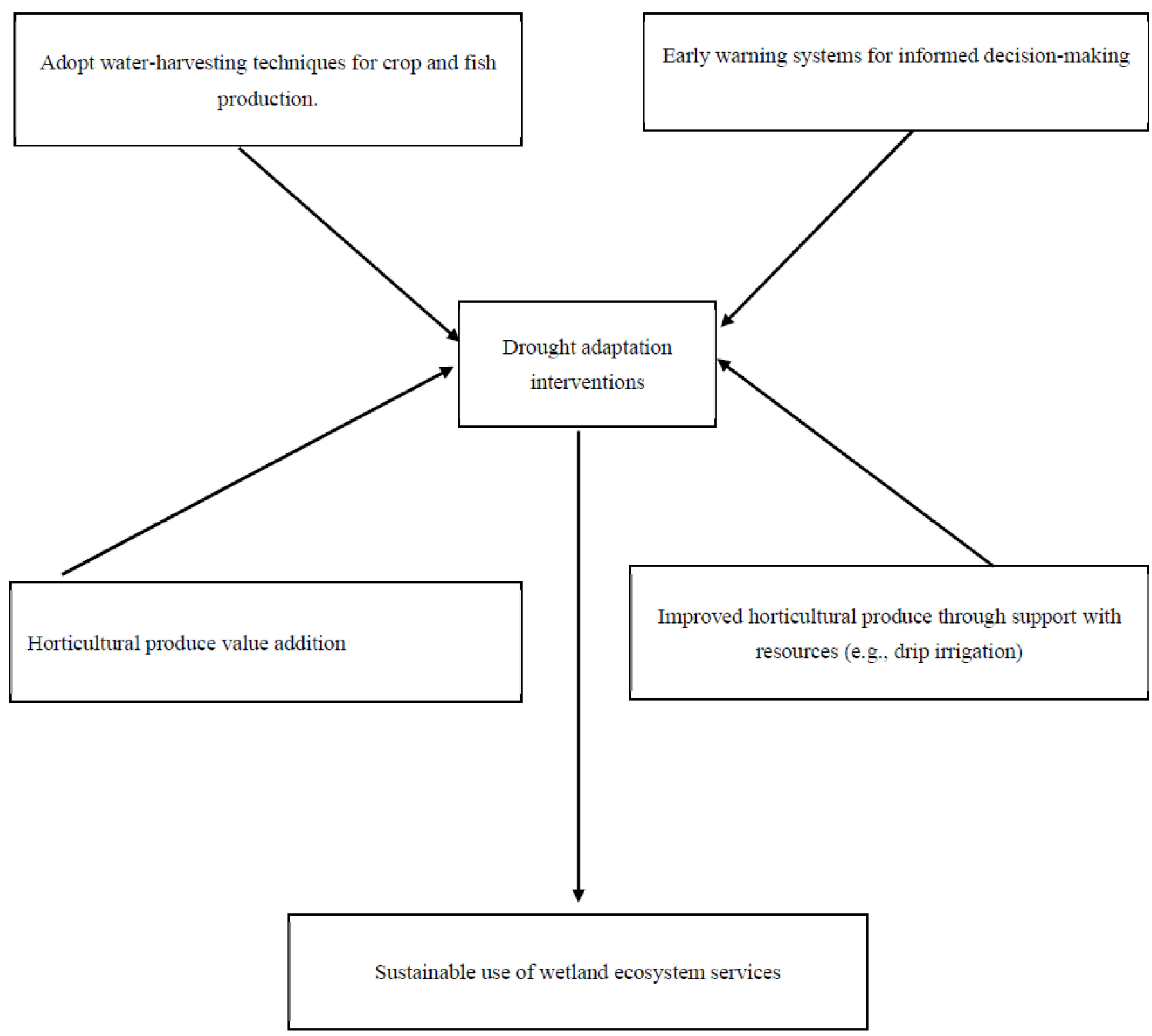

Figure 9. Proposed framework to enhance rural livelihood coping strategies in response to the impact of drought on wetland ecosystem.

\section{Conclusions}

This article assessed the local peoples' perceptions on the impact of the frequency and severity of drought on the wetland's ecosystem services and the associated livelihood benefits in a rural area of Zimbabwe. The results of the study show that the livelihoods of the local community that are largely dependent on the Driefontein wetland are at risk due to the persisting high frequency of drought. Clean water for domestic use, livestock pasture, moist conditions for crop farming, habitat for endangered crane bird species and the wetland's aesthetic value are severely affected by drought. Due to the limited livelihood 
options of households as they rely on wetland crop farming and livestock production, drought has resulted in the intensification and expansion of agricultural activities in and around the wetland, resulting in hydrological changes and the alteration of the vegetation structure and composition. Inadvertently, human uses of the wetland as a result of drought are also further exacerbating the degradation of the wetland's ecosystem services.

The perceived impact of drought on human livelihood options calls for the identification of drought adaptation strategies that will build the resilience of wetland-dependent communities. This will go a long way in assisting with the achievement of the United Nations Sustainable Development Goals (2015 to 2030) on no poverty and zero hunger since the studied community's livelihoods are largely dependent of the wetland. It is worth noting that despite the impact of drought on the wetland's conditions, human wetland activities remain the major source of the households' economy. There is also a need for longitudinal research to measure the rainfall patterns and wetland-catchment water level variations as well as water quality changes during periods of drought in relation to the existing land uses. This will provide baseline information towards promoting the wise use of wetlands during times of drought. This restrictive environmental factor suggests evaluating for cultivation purposes crops that have a low water demand, suitable for drought conditions, starting from local genetic resources, as the crop wild relatives, and also the priority ones, because we must also consider the conservation strategy aspects in a protected area such as the Ramsar site.

The findings of this study have potential implications in the conservation of wetlands in other parts of Zimbabwe and elsewhere in the world where drought has negatively affected ecosystem service provision. The consequences of drought have been far reaching both for human consumptive uses and for aquatic ecosystems. The response to the drought from scientists and natural resources managers has been both haphazard and uncoordinated. Management responses to drought are also typically reactive and fail to consider uncertainties in the potential duration of drought events. Therefore, the approaches to managing drought must be rethought. As the severity of the drought was realised in Driefontein and many parts of Zimbabwe, concern from both the local communities and government organizations grew rapidly. However, research seeking to document the impacts of the drought has been hampered by little existing baseline research, limited dedicated funding and a lack of extensive pre-drought data in the worst-affected areas. Moreover, field measurements need to be carried out to further understand the wetland water level dynamics.

Author Contributions: Conceptualization, T.M. (Thomas Marambanyika); methodology, T.M. (Thomas Marambanyika); T.M. (Tatenda Musasa); U.N.M. and K.N.; Software, T.M. (Tatenda Musasa) and U.N.M.; validation, T.M. (Thomas Marambanyika) and U.N.M.; formal analysis, T.M. (Thomas Marambanyika); T.M. (Tatenda Musasa); U.N.M. and K.N.; investigation, T.M. (Thomas Marambanyika); T.M. (Tatenda Musasa); U.N.M. and K.N.; resources, T.M. (Thomas Marambanyika); data curation, T.M. (Tatenda Musasa); writing—original draft preparation, T.M. (Thomas Marambanyika) and T.M. (Tatenda Musasa); writing-review and editing, T.M. (Thomas Marambanyika), T.M. (Tatenda Musasa); U.N.M. and K.N.; visualization, T.M. (Thomas Marambanyika). All authors have read and agreed to the published version of the manuscript.

Funding: This article is part of study that is being funded by the Wetland Monitoring and Assessment Services for Transboundary Basins of Southern Africa (WeMAST) Project under the GMES and Africa programme.

Data Availability Statement: The data presented in this study are available on request from the corresponding author. The data are not publicly available due to the need to ensure anonymity and confidentiality of the responses as agreed in the consent form that outlined the basis for the participants' participation in this study.

Acknowledgments: The authors acknowledge all the community members who participated in the study.

Conflicts of Interest: The authors declare no conflict of interest. 


\section{References}

1. Davidson, N.C.; Fluet-Chouinard, E.; Finlayson, C.M. Global extent and distribution of wetlands: Trends and issues. Mar. Freshw. Res. 2018. [CrossRef]

2. Ramsar Convention Secretariat. Global Wetland Outlook: State of the World's Wetlands and Their Services to People; Ramsar Convention Secretariat: Gland, Switzerland, 2018.

3. Rebelo, L.M.; McCartney, M.P.; Finlayson, C.M. Wetlands of Sub-Saharan Africa: Distribution and contribution of agriculture to livelihoods. Wetl. Ecol. Manag. 2010, 18, 557-572. [CrossRef]

4. Musasa, T.; Marambanyika, T. Threats to sustainable utilization of wetland resources in Zimbabwe: A review. Wetl. Ecol. Manag. 2020. [CrossRef]

5. Junk, W.J.; An, S.; Finlayson, C.M.; Gopal, B.; Květ, J.; Mitchell, S.A.; Mitsch, W.J.; Robarts, R.D. Current state of knowledge regarding the world's wetlands and their future under global climate change: A synthesis. J. Aquat. sci. 2013, 75, 151-167. [CrossRef]

6. Millennium Ecosystem Assessment. Ecosystems and Human Well-Being; Island Press: Washington, DC, USA, 2005.

7. Erwin, K.L. Wetlands and global climate change: The role of wetland restoration in a changing world. Wetl. Ecol. Manag. 2009, 17, 71-84. [CrossRef]

8. Mitsch, W.J.; Bernal, B.; Hernandez, M.E. Ecosystem services of wetlands. Int. J. Biodivers. Sci. Ecosyst. Serv. Manag. 2015, 11, 1-4. [CrossRef]

9. Madebwe, V.; Madebwe, C. An exploratory analysis of the social, economic and environmental impacts on wetlands: The Case of Shurugwi District, Midlands Province, Zimbabwe. J. Appl. Sci. Res. 2005, 1, 228-233.

10. Chiputwa, B.; Morardet, S.; Mano, R. Diversity of wetland-based livelihoods in Limpopo River Basin. In Proceedings of the 7th Waternet Symposium "Mainstreaming IWRM in the Development Process", Lilongwe, Malawi, 1-3 November 2006; WaterNet: Amsterdam, The Netherlands, 2006. Available online: https://hdl.handle.net/10568/21599 (accessed on 16 July 2020).

11. Finlayson, C.M.; Pollard, S.A. Framework for Undertaking Wetland Inventory Assessment and Monitoring in the Limpopo Basin Southern Africa; CPWF Project Report; CGIAR Challenge Program on Water and Food: Colombo, Sri Lanka, 2009.

12. Mahlatini, P.; Hove, A.; Maguma, A.F.; Chemura, A. Using direct use values for economic valuation of wetland ecosystem services: A case of Songore wetland, Zimbabwe. GeoJournal 2018. [CrossRef]

13. Kotze, D.; Malan, H. WET-Sustainable Use: A System for Assessing the Sustainability of Wetland Use; Water Research Commission: Pretoria, South Africa, 2010.

14. Macfarlane, D.; Kotze, D.C.; Ellery, W.N.; Walters, D.; Koopman, V.; Goodman, P.; Goge, C. WET-Health: A Technique for Rapidly Assessing Wetland Health; Water Research Commission: Pretoria, South Africa, 2009.

15. Xu, T.; Weng, B.; Yan, D.; Wang, K.; Li, X.; Bi, W.; Li, M.; Cheng, X.; Liu, Y. Wetlands of international importance: Status, threats, and future protection. Int. J. Environ. Res. Public Health 2019, 16, 1818. [CrossRef]

16. Mitchell, S.A. The status of wetlands, threats and the predicted effect of global climate change: The situation in Sub-Saharan Africa. J. Aquat. Sci. 2013, 75, 95-112. [CrossRef]

17. Pantshwa, A.O.; Buschke, F.T. Ecosystem services and ecological degradation of communal wetlands in a South African biodiversity hotspot. R. Soc. Open Sci. 2019, 6, 1-11.

18. Ruppel, O.C.; Ruppel-Schlichting, K. Environmental Law and Policy in Namibia: Towards Making Africa the Tree of Life; Hanns Seidel Foundation: Windhoek, Namibia, 2016.

19. Finlayson, C.M.; Davis, J.A.; Gell, P.A.; Kingsford, R.T.; Parton, K.A. The status of wetlands and the predicted effects of global climate change: The situation in Australia. Aquat. Sci. 2013, 75, 1-21. [CrossRef]

20. Seneviratne, S.I.; Nicholls, N.; Easterling, D.; Goodess, C.M.; Kanae, S.; Kossin, J.; Luo, Y.; Marengo, J.; McInnes, K.; Rahimi, M.; et al. Changes in climate extremes and their impacts on the natural physical environment. In Managing the Risks of Extreme Events and Disasters to Advance Climate Change Adaptation; A Special Report of Working Groups I and II of the Intergovernmental Panel on Climate Change, (IPCC); Field, C.B., Van Barros, T.F., Stocker, D., Qin, D.J., Dokken, K.L., Ebi, M.D., Mastrandrea, K.J., Mach, G.-K., Plattner, S.K., Allen, M., et al., Eds.; Cambridge University Press: Cambridge, UK; New York, NY, USA, 2012; pp. 109-230.

21. Masik, I.; Maskey, S.; Mussa, F.; Trambauer, P. A review of droughts on the African continent: A geospatial and long-term perspective. Hydrol. Earth Syst. Sci. 2014, 18, 3635-3649.

22. Lloréns, J.L. Impacts of Climate Change on Wetland Ecosystems. 2008. Available online: https://www.zaragoza.es/contenidos/ medioambiente/cajaAzul/10S3-P2-Perez\%20LloresnACC.pdf (accessed on 12 July 2020).

23. Mazvimavi, D. Investigating changes over time of annual rainfall in Zimbabwe. J. Hydrol. Earth Syst. Sci. 2010, 14, 2671-2679. [CrossRef]

24. Nangombe, S.S. Drought conditions and management strategies in Zimbabwe. In Proceedings of the Regional Workshops on Capacity Development to Support National Drought Management Policies for Eastern and Southern Africa and the Near East and North Africa Regions, Addis Ababa, Ethiopia, 5-8 August 2015.

25. Frischen, J.; Meza, I.; Rupp, D.; Wietler, G.; Hagenlocher, M. Drought Risk to Agricultural Systems in Zimbabwe: A Spatial Analysis of Hazard, Exposure, and Vulnerability. Sustainability 2020, 12, 752. [CrossRef]

26. Mushore, T.D. Effectiveness of drought mitigation strategies in Bikita District, Zimbabwe. Int. J. Environ. Protect. Policy 2013, 1, 101. [CrossRef] 
27. Niang, I.O.C.; Ruppel, M.A.; Abdrabo, A.; Lennard, E.C.; Padgham, J.; Urquhart, P. Climate Change Impacts, Adaptation, and Vulnerability. Part B: Regional Aspects. Contribution of Working Group II to the Fifth Assessment Report of the Intergovernmental Panel on Climate Change; Barros, V.R., Field, C.B., Dokken, D.J., Mastrandrea, M.D., Mach, K.J., Bilir, T.E., Chatterjee, M., Ebi, K.L., Estrada, Y.O., Genova, R.C., et al., Eds.; Cambridge University Press: Cambridge, UK; New York, NY, USA, 2014; pp. $1199-1265$.

28. Kinsey, B.; Burger, K.; Gunning, W. Coping with drought in Zimbabwe: Survey evidence on responses of rural households to risk. World Dev. 1998, 26, 89-110. [CrossRef]

29. Zimbabwe National Statistics Agency Zimbabwe. Poverty Report 2017; Zimstat: Harare, Zimbabwe, 2019.

30. Marambanyika, T.; Beckedahl, H.; Ngetar, N.S. Community strategies to promote sustainable wetland-based food security in rural areas of Zimbabwe. GeoJournal 2016, 82, 987-1003. [CrossRef]

31. Kokwe, M. The role of dambos in agricultural development in Zambia. In Wetlands in Drylands: The agroecology of Savanna Systems in Africa; Scoones, I., Ed.; International Institute for Environment and Development: London, UK, 1991; pp. 1-35.

32. Bell, M.; Faulkner, R.; Hotchkiss, P.; Lambert, R.; Roberts, N.; Windram, A. The Use of Dambos in Rural Development, with Reference to Zimbabwe; Final Report of ODA Project R3869; Loughborough University: Loughborough, UK; University of Zimbabwe: Harare, Zimbabwe, 1987; pp. 1-147.

33. Marambanyika, T.; Beckedahl, H. Wetland utilization patterns in semi-arid communal areas of Zimbabwe between 1985 and 2013 and the associated benefits to livelihoods of the surrounding communities. Trans. R. Soc. S. Afr. 2016, 71, 175-186. [CrossRef]

34. Whitlow, R. Conservation status of wetlands in zimbabwe: Past and present. GeoJournal 1990, 20, 191-202. [CrossRef]

35. Marambanyika, T.; Beckedahl, H. The missing link between awareness and the implementation of wetland policy and legislation in communal areas of Zimbabwe. Wetl. Ecol. Manag. 2016, 24, 545-563. [CrossRef]

36. Bhaga, T.D.; Dube, T.; Shekede, M.D.; Shoko, C. Impacts of climate variability and drought on surface water resources in Sub-Saharan Africa using remote sensing: A review. Remote Sens. 2020, 12, 4184. [CrossRef]

37. Moyo, M.; Mvumi, B.M.; Kunekweguta, M.; Mazvimavi, K.; Craufurd, P.; Dorward, P. Farmer perceptions on climate change and variability in semi-arid Zimbabwe in relation to climatology evidence. Afr. Crop Sci. J. 2012, 20, 317-335.

38. Slegers, M.F.W. If only it would rain: Farmers' perceptions of rainfall and drought in semi-arid central Tanzania. J. Arid Environ. 2008, 72, 2106-2123. [CrossRef]

39. Rahim, H.; Shamsudin, M.N.; Radam, A.; Ghani, A.N.A. Factors affecting user's perception towards Tasek Bera wetland area in Pahang. Econ. Technol. Manag. Rev. 2014, 9, 171-179.

40. Crecious, H.; Lazarus, C. Human perceptions on degradation of wetland ecosystems: The case of Magwenzi Wetland in Chivi District; Zimbabwe. Greener J. Geol. Earth Sci. 2013, 1, 13-22.

41. Nath, T.K.; Dahalan, M.P.B.; Parish, F.; Rengasamy, N. Local peoples' appreciation on and contribution to conservation of peatland swamp forests: Experience from Peninsular Malaysia. Wetlands 2017, 37, 1067-1077. [CrossRef]

42. Nhemachena, C.; Mano, R.; Mudombi, S.; Muwanigwa, V. Perceptions on climate change and its impact on livelihoods in Hwange district, Zimbabwe. Jàmbá J. Disaster Risk Stud. 2014, 6, 123. [CrossRef]

43. Camacho-Valdez, V.; Saenz-Arroyo, A.; Ghermandi, A.; Navarrete-Gutiérrez, D.A.; Rodiles-Hernández, R. Spatial analysis, local people's perception and economic valuation of wetland ecosystem services in the Usumacinta floodplain, Southern Mexico. Peer 2020, 8, e8395. [CrossRef]

44. Ndiweni, N.J.; Gwate, O. Public perceptions of climate variability risks on wetland management: A case of ward 15 of Matobo North District, Zimbabwe. Asian J. Soc. Sci. Hum. 2013, 3, 28-38.

45. Mandishona, E.; Knight, J. Users' perceptions and understanding of two urban wetlands in Harare, Zimbabwe. S. Afr. Geogr. J. 2019, 101, 326-348. [CrossRef]

46. Creitaru, I. Capacity Assessment of the Disaster Risk Management System in Zimbabwe. 2017. Available online: https: //www.cadri.net/sites/default/files/Zimbabwe-Report-May-2017.pdf (accessed on 6 January 2021).

47. Fakarayi, T.; Mashapa, C.; Gandiwa, E.; Kativu, S. Pattern of Land-Use and Land Cover Changes in Driefontein Grassland Important Bird Area, Zimbabwe', Tropical Conservation Science; SAGE Publications Sage CA: Los Angeles, CA, USA, 2015; Volume 8, pp. $274-283$.

48. Fakarayi, T.; Mashapa, C.; Gandiwa, E.; Kativu, S. 'Varying land-use has an influence on wattled and grey crowned cranes' abundance and distribution in Driefontein Grasslands important bird area, Zimbabwe. PLoS ONE 2016, 11, e0166209. [CrossRef] [PubMed]

49. Austin, J.E.; Sundar, K.S.G. Methods to Reduce Conflicts between Cranes and Farmers', Cranes and Agriculture: A Global Guide for Sharing the Landscape; International Crane Foundation: Baraboo, WI, USA, 2018; pp. 117-141.

50. Mugandani, R.; Wuta, M.; Makarau, A.; Chipindu, B. Re-classification of agro-ecological regions of Zimbabwe in conformity with climate variability and change. Afr. Crop Sci. J. 2012, 20, 361-369.

51. Zimbabwe National Statistics Agency. The Food Poverty Atlas: Small Area Food Poverty Estimation; Zimstat: Harare, Zimbabwe, 2016.

52. Birdlife Zimbabwe. Zimbabwe's Important Bird Areas: National Status Report; Birdlife Zimbabwe: Harare, Zimbabwe, 2009.

53. Braun, V.; Clarke, V. Using thematic analysis in psychology. Qual. Res. Psychol. 2006, 3, 77-101. [CrossRef]

54. Bond, N.R.; Lake, P.S.; Arthington, A.H. The impacts of drought on freshwater ecosystems: An Australian perspective. Hydrobiologia 2008, 3-16. [CrossRef]

55. Chang, H.; Bonnette, M.R. Climate change and water-related ecosystem services: Impacts of drought in California, USA. Ecosyst. Health Sustain. 2017, 2. [CrossRef] 
56. Nyahunda, L.; Tirivangasi, H.M. Challenges faced by rural people in mitigating the effects of climate change in the Mazungunye communal lands, Zimbabwe. Jamba J. Disaster Risk Stud. 2019, 11, 596. [CrossRef]

57. Marambanyika, T.; Beckedahl, H.; Ngetar, N.S.; Dube, T. Assessing the environmental sustainability of cultivation systems in wetlands using the WET-health framework in Zimbabwe. Phys. Geogr. 2016, 38, 62-82. [CrossRef]

58. Stirling, E.; Fitzpatrick, R.W.; Mosley, L.M. Drought effects on wet soils in inland wetlands and peatlands. Earth Sci. Rev. 2020, 210, 103387. [CrossRef]

59. Payus, C.; Huey, L.A.; Adnan, F.; Rimba, A.B.; Mohan, G.; Chapagain, S.K.; Roder, G.; Gasparatos, A.; Fukushi, K. Impact of extreme drought climate on water security in north borneo: Case study of Sabah. Water 2020, 12, 1135. [CrossRef]

60. Lake, P.S. Ecological effects of perturbation by drought in flowing waters. Freshw. Biol. 2003, 48, 1161-1172. [CrossRef]

61. Reiter, M.E.; Elliott, N.K.; Jongsomjit, D.; Golet, G.H.; Reynolds, M.D. Impact of extreme drought and incentive programs on flooded agriculture and wetlands in California's Central Valley. PeerJ Life Environ. 2018, 6, 5147. [CrossRef] [PubMed]

62. Zedler, J.B.; Kercher, S. Causes and consequences of invasive plants in wetlands: Opportunities, opportunists, and outcomes. Crit. Rev. Plant Sci. 2004, 23, 431-452. [CrossRef]

63. Howard, G.W.; Matindi, S.W. Alien Invasive Species in Africa's Wetlands: Some Threats and Solutions; IUCN Eastern Africa Regional Programme: Nairobi, Kenya, 2003.

64. Ongoro, W. Assessing the Effectiveness of National Wetland Adaptation and Management Frameworks in Kenya; the Case of Nyando Wetland Ecosystem. Unpublished Dissertation, University of Ottawa, Ottawa, ON, Canada, 2017.

65. Lunduka, R.W.; Mateva, K.I.; Magorokosho, C.; Manjeru, P. Impact of adoption of drought-tolerant maize varieties on total maize production in south Eastern Zimbabwe. Clim. Dev. 2019, 11, 35-46. [CrossRef] [PubMed]

66. Ncube, N.; Tanga, P.T.; Bhumira, B. The impact of de-agrarianisation on the socio-economic well-being of rural inhabitants in South Africa. J. Hum. Ecol. 2014, 48, 399-406. [CrossRef]

67. Loison, S.A. Rural livelihood diversification in sub-saharan africa: A literature review. J. Dev. Stud. 2015, 51, 1125-1138. [CrossRef]

68. Pandey, S.M.; Upadhyay, J.N. Effects of drought on rural population: Findings of an area study. Indian J. Ind. Relat. 1979, 15, 251-305. 